\title{
Super-capacitor energy storage system to recuperate regenerative braking energy in elevator operation of high buildings
}

\author{
An Thi Hoai Thu Anh, Luong Huynh Duc
}

Department of Electrical Engineering, Faculty of Electrical-Electronic Engineering, University of transport and communications, Hanoi, Vietnam

\begin{tabular}{l} 
Article Info \\
\hline Article history: \\
Received Mar 2, 2021 \\
Revised Sep 14, 2021 \\
Accepted Oct 10, 2021 \\
\hline Keywords: \\
Bidirectional DC-DC converter \\
Energy saving \\
Mechanical elevator \\
Regenerative braking \\
Super-capacitor energy storage \\
system
\end{tabular}

\begin{abstract}
In operating phases of elevators, accelerating, braking modes occur frequently, so braking energy recuperation of elevators has contributed considerably to decrease the total electric energy consumption for operating elevators in multi-floor buildings. In this paper, the supercapacitor energy storage system is used to recover regenerative braking energy of elevators when they operate down full-load and up no-load, reducing fluctuation of voltage on DC bus as well. Therefore, super-capacitor energy storage system (SCESS) will be parallel with line utility to recuperate regenerative braking energy in braking phase and support energy for acceleration phase. The surplus energy will be stored in the supercapacitors thanks to a DC-DC converter capable of exchanging energy bidirectionally in buck/boost modes, and designing control strategy including two control loops. Inner loopcurrent loop: controlling charge/discharge process of supercapacitors by current iL complying with operation characteristic of elevator; Outer loopvoltage loop: managing UDC-link at a fixed value. Simulation results with elevator system of the ten-floor building, Hanoi, Vietnam installed SCESS have been verified on MATLAB Simulink, SimPowerSystem with saving energy level about $30 \%$.
\end{abstract}

This is an open access article under the CC BY-SA license.

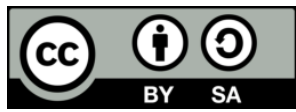

\section{Corresponding Author:}

An Thi Hoai Thu Anh

Department of Electrical Engineering, Faculty of Electrical-Electronic Engineering

University of Transport and Communications

No 3 Cau Giay, Lang Thuong Commune, Dong Da District, Hanoi, Vietnam

Email: htanh.ktd@utc.edu.vn

\section{INTRODUCTION}

In elevator operation, regenerative braking energy is mainly dissipated on braking resistors [1], [2]. Therefore, how to reduce energy consumption in these vertical transportation systems has long been one of hot research issues to pay much attention from scientists, engineers. With rapid growth of power electronics converters, traction motor making easier for many saving energy solutions in elevator operation to be performed [3]-[9].

Figure 1 showed three groups of solutions for saving energy in elevator operation: Recuperating regenerative braking energy, reducing the energy consumption of comfort functions, enhancing traction efficiency. Among them, percentage of recovering regenerative braking energy is the highest. This solution group can be divided into two categories: the direct use of regenerative energy by matching time of accelerating and braking elevators by timetable optimization using the optimal control theory so that regenerative braking energy of elevators operating in power generation state transfers to elevators operating 
in motoring state [10], [11], and the indirect use of regenerative energy by applying energy storage devices recovering braking energy when elevators operate in no-load lifting, and full-load lowering [12]-[17], or active rectifiers, reversible rectifiers in order to back the braking energy to the grid source [18]-[20]. This paper proposes the method for recovering regenerative braking energy by the super-capacitor energy storage system (SCESS) with the saving energy percentage indicated in the simulation results on MATLAB of the building ten floor being up to $30 \%$.

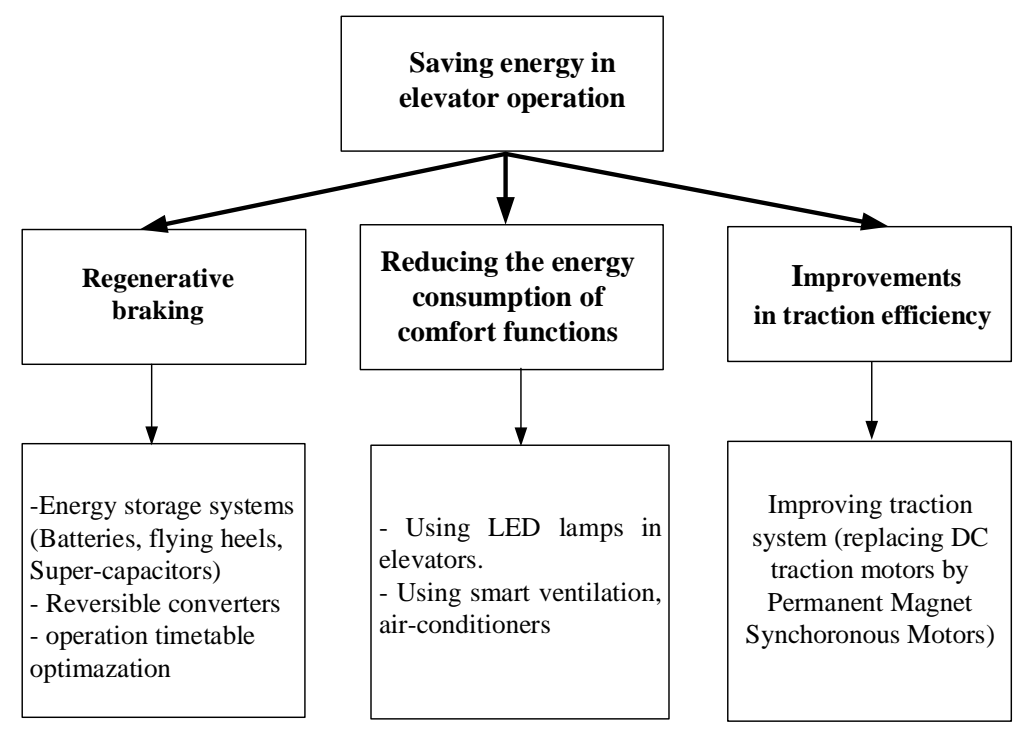

Figure 1. Block diagram of energy saving solutions in elevator operation

\section{MODELING ELEVATOR SYSTEM}

The structure for the full elevator system shown in Figure 2 includes the diode rectifier, elevator drive system, a bank of supercapacitors with bidirectional DC-DC converter paralleled to the DC bus. Modelling some main parts has been performed briefly.

\subsection{Modelling traction motor}

The traction motor is a cage induction motor. The induction motor model in the $d-q$ reference frame is obtained [21], [22]:

$$
\left\{\begin{array}{l}
\frac{d i_{s d}}{d t}=-\left(\frac{1}{\sigma T_{s}}+\frac{1-\sigma}{\sigma T_{r}}\right) i_{s d}+\omega_{s} i_{s q}+\frac{1-\sigma}{\sigma T_{r}} \psi_{r d}^{\prime}+\frac{1-\sigma}{\sigma} \omega \psi_{r q}^{\prime}+\frac{1}{\sigma L_{s}} u_{s d} \\
\frac{d i_{s q}}{d t}=-\left(\frac{1}{\sigma T_{s}}+\frac{1-\sigma}{\sigma T_{r}}\right) i_{s q}-\omega_{s} i_{s d}+\frac{1-\sigma}{\sigma T_{r}} \psi_{r q}^{\prime}-\frac{1-\sigma}{\sigma} \omega \psi_{r d}^{\prime}+\frac{1}{\sigma L_{s}} u_{s q} \\
\frac{d \psi_{r d}}{d t}=\frac{L_{m}}{T_{r}} i_{s d}-\frac{1}{T_{r}} \psi_{r d}+\left(\omega_{s}-\omega\right) \psi_{r q} \\
\frac{d \psi_{r q}}{d t}=\frac{L_{m}}{T_{r}} i_{s q}-\left(\omega_{s}-\omega\right) \psi_{r d}-\frac{1}{T_{r}} \psi_{r q} \\
m_{M}=\frac{3}{2} z_{p} \frac{L_{m}^{2}}{L_{r}} \psi_{r d}^{\prime} i_{s q}=\frac{3}{2} z_{p}(1-\sigma) L_{s} \psi_{r d}^{\prime} i_{s q} \\
m_{M}=m_{L}+\frac{J}{z_{p}} \frac{d \omega}{d t}
\end{array}\right.
$$

where the parameters are defined as: $\psi_{r d}^{\prime}=\psi_{r d} / L_{m}$ và $\psi_{r q}^{\prime}=\psi_{r q} / L_{m}, \sigma=1-\frac{L_{m}^{2}}{L_{s} L_{r}}$ : leakage factor, $T_{S}=\frac{L_{s}}{R_{S}}:$ stator time constant, $T_{r}=\frac{L_{r}}{R_{r}}$ : rotor time constant, $T_{\sigma}^{\prime}=\frac{\sigma L_{\sigma}}{r_{\sigma}}, \omega_{s}=\omega+\frac{L_{m}}{T_{r}} \frac{i_{S d}}{\psi_{r d}}:$ slip estimation, $\omega$ : mechanical rotor speed, $z_{p}$ : number of pole pairs, $J$ : Moment of inertia, $m_{L}$ : Load torque, $\psi_{r d}, \psi_{r q}$ : rotor flux, and $L_{m}, L_{r}, L_{s}$ : mutual, rotor, and stator inductance. 


\subsection{Determining static loads}

Calculating static loads in order to determine power of traction motor. The tensile forces exerted on the active pulley along the cable branches are:

$$
\begin{aligned}
& F_{1}=\left[G_{c b}+G_{t}+G_{c}\left(H-H_{c b}\right)\right] \cdot g(\mathrm{~N}) \\
& F_{2}=\left[G_{d t}+G_{c}\left(H-H_{d t}\right)\right] \cdot g(N)
\end{aligned}
$$

Total force exerted on active pulley when lifting and lowering full load:

$$
\begin{aligned}
& F_{n}=F_{1}-F_{2}=\left(G_{c b}+1000-G_{d t}\right) g+G_{c}\left(H_{d t}-H_{c b}\right) g(\mathrm{~N}) \\
& F_{h}=F_{2}-F_{1}=\left(G_{d t}-G_{c b}-1000\right) g+G_{c}\left(H_{c b}-H_{d t}\right) g(N)
\end{aligned}
$$

where: $F_{n}, F_{h}$ : Lifting, lowering forces, $\mathrm{G}_{\mathrm{dt}}$ : Counter-weight mass $(\mathrm{Kg}), \mathrm{G}_{\mathrm{c}}$ : Mass of a cable length unit $(\mathrm{Kg} / \mathrm{m}), \mathrm{G}_{\mathrm{t}}$ : Load mass, $\mathrm{H}_{\mathrm{dt}}$ : Counterweight height $(\mathrm{m}), \mathrm{H}_{\mathrm{cb}}$ : Cabin heigth $(\mathrm{m}), \mathrm{g}$ : Acceleration of gravity $\left(\mathrm{g}=9.8 \mathrm{~m} / \mathrm{s}^{2}\right)$. The torque converted to the motor shaft calculated by the traction force:

$$
M=\frac{F . R}{i . \eta} \text { if } F>0 ; M=\frac{F . R}{i} \eta \text { if } F<0
$$

R: Cable pulley radius, i: Gear ratio, $\eta$ : Transmitter efficiency.

Full load lifting torque converted to motor shaft:

$$
M_{1}=\frac{G_{c b}+G d t_{\text {tmax }}}{i . \eta}
$$

No-load lifting torque converted to motor shaft:

$$
M_{2}=\frac{G_{c b}-G_{d t}}{i} g \cdot R \cdot \eta
$$

Torque lowering full load converted to motor shaft:

$$
M_{3}=\frac{G_{c b}+G d t_{t \max }}{i}
$$

Torque lowering no-load double to the motor shaft:

$$
M_{4}=\frac{G_{c b}-G_{d t}}{i . \eta} g . R
$$

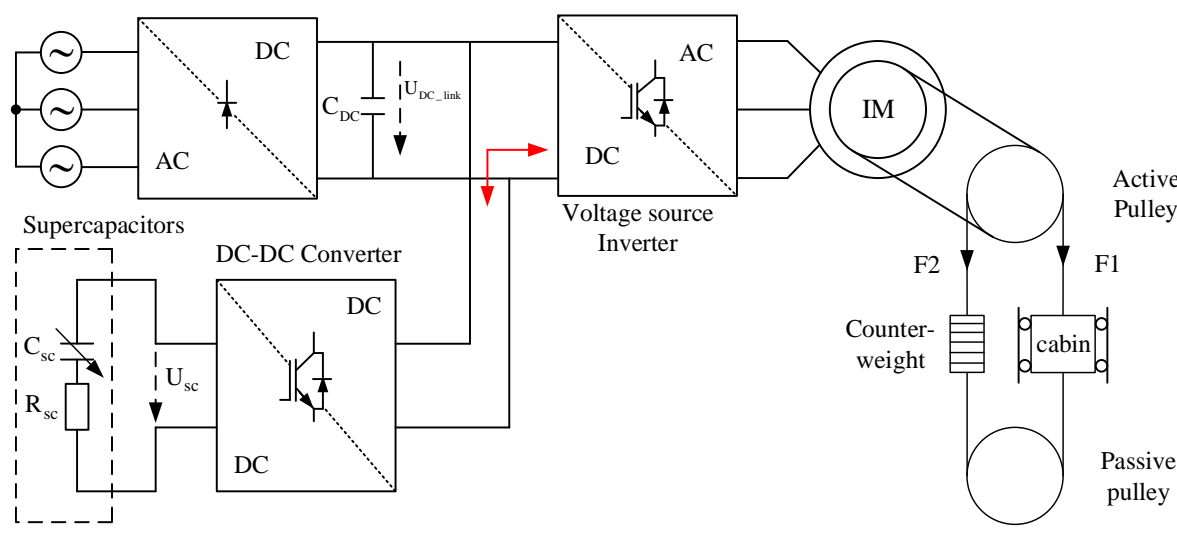

Figure 2. Elevator drive system with induction motor and energy recovery braking 


\subsection{Modeling bidirectional DC-DC converter}

Power circuit diagram of the DC-DC converter shown in Figure 3 being capable of flowing energy bidirectionally from SCESS to traction motor and vice versa [23]-[25] operates in buck or boost modes because voltage on DC bus is high, voltage on supercapacitor is low.

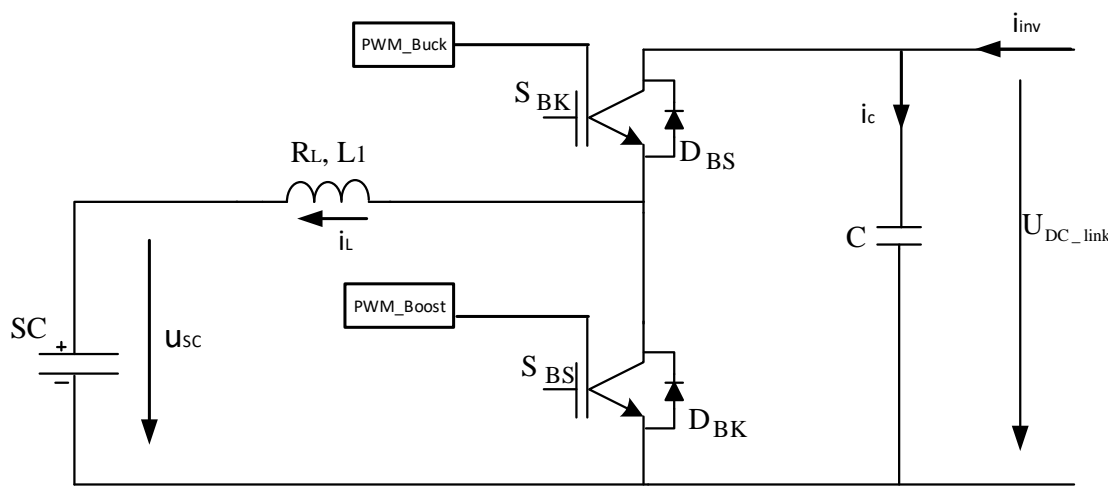

Figure 3. Buck-boost converter schematics

Equivalent circuit of bidirectional DC-DC converter is demonstrated in Figure 4, an ideal transformer is replaced for switches with $d(t)$ being transformer factor, and $\left\{\begin{array}{l}u_{1}(t)=d(t) u_{2}(t) \\ i_{2}(t)=d(t) i_{1}(t)\end{array}\right.$, Mathematic model of the DC-DC is written [26]:

$$
\left\{\begin{array}{l}
L \frac{d i_{L}}{d t}=-R_{L} i_{L}+d u_{D C_{-} \text {link }}-u_{S C} \\
C \frac{d u_{D C_{-} l i n k}}{d t}=-d i_{L}+i_{\text {inv }}
\end{array}\right.
$$

where control variable - duty ratio $(d)$, the state variables $-i_{L}, u_{D C_{-} l i n k}$.

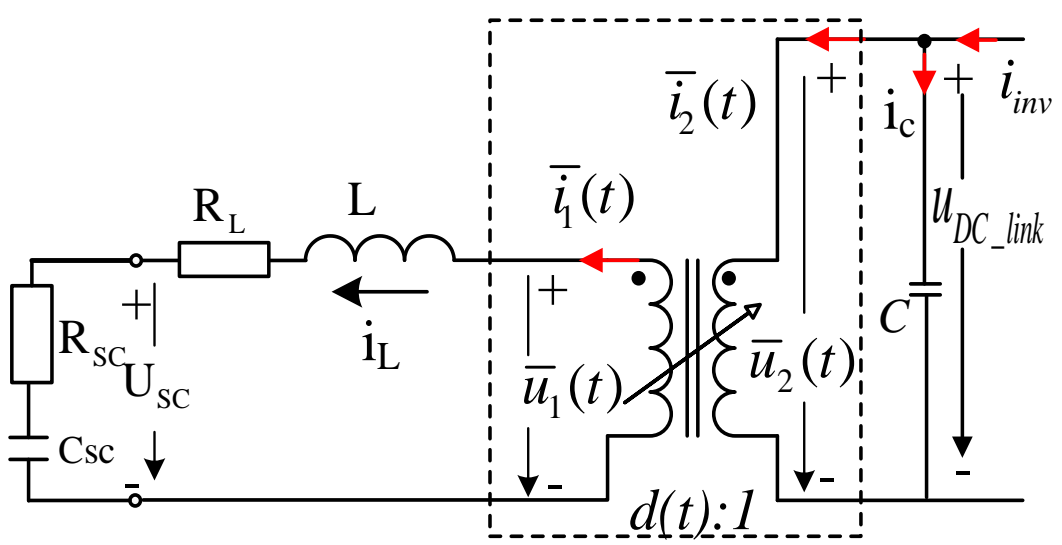

Figure 4. Equivalent circuit of DC-DC converter

\section{CONTROL DESIGN FOR ELEVATOR SYSTEM}

Designing control for elevator system comprises of designing field-oriented control (FOC) for elevator drive motor [21] and designing control for the bidirectional DC-DC converter [25]. However, in this section, focusing on controlling the DC-DC converter. Hence, using two - loop cascaded control structure is also called current mode control (CMC) [26] as shown in Figure 5. The outer loop is the voltage loop regulating error between $u_{D C \text {-linhk }}$ and $u_{D C-\text { link }}^{*}$, which creating the current reference for the inner current 
loop. The inner loop controls $i_{L^{-}}$the inductor current in order to controlling charge or discharge process of super-capacitor system in an accordance with the elevator operation characteristic.

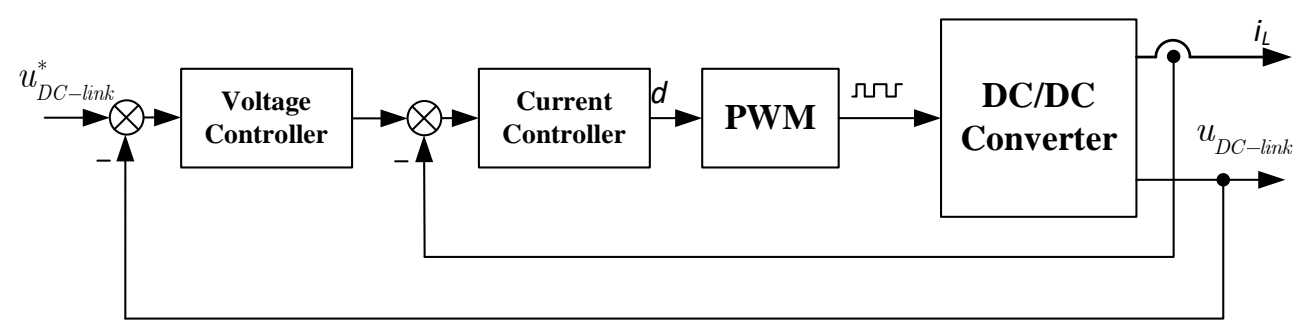

Figure 5. CMC structure for DC-DC converter

\subsection{Design control of the current-loop}

The inner loop controls charge and discharge process of supercapacitor. From the first equation of (11), building up the small-signal model.

$$
\frac{d \tilde{l}_{L}(t)}{d t}=-\frac{R_{L}}{L} \cdot \tilde{l}_{L}(t)+\frac{1}{L} \cdot \tilde{d}(t) \cdot U_{D C_{-} l i n k}+\frac{1}{L} \cdot D \cdot \tilde{u}_{D C_{-} l i n k}(t)+\frac{1}{L} \cdot \tilde{u}_{s c}(t)
$$

In steady state, $\mathrm{u}_{\mathrm{SC}}$ may be considered as constant in steady state so regarding as constant disturbance for the control loop. Therefore, the transfer function of the inductor current is computed:

$$
G_{p i}(s)=\frac{\tilde{\imath}_{L}(s)}{\tilde{d}(s)}=\frac{U_{D C_{\_} l i n k}}{L s+R_{L}}
$$

The current controller PI with transfer function:

$$
G_{C i}(s)=k_{p}+\frac{k_{i}}{s}=\frac{T_{i} s+1}{T_{a} s}
$$

with $T_{i}=\frac{k_{p}}{k_{i}} ; T_{a}=\frac{1}{k_{i}} ; T_{n l}$ : delay time caused by PWM. The closed-loop transfer function of Figure 6 is given:

$$
G_{S i}(s)=\frac{U_{D C_{-} \text {link }} / R_{L}}{T_{a} \cdot s\left(1+T_{n l \cdot} \cdot s\right)+U_{D C_{-} \text {link }} / R_{L}}
$$

Using module optimal method determines [27]:

$$
T_{i}=\frac{L}{R_{L}} ; K_{p}=\frac{L}{2 . U_{D C_{-} \text {link }} \cdot T_{n l}} ; K_{i}=\frac{K_{p}}{T_{i}}=\frac{R_{L}}{2 . U_{D C_{-} \text {link }} \cdot T_{n l}}
$$

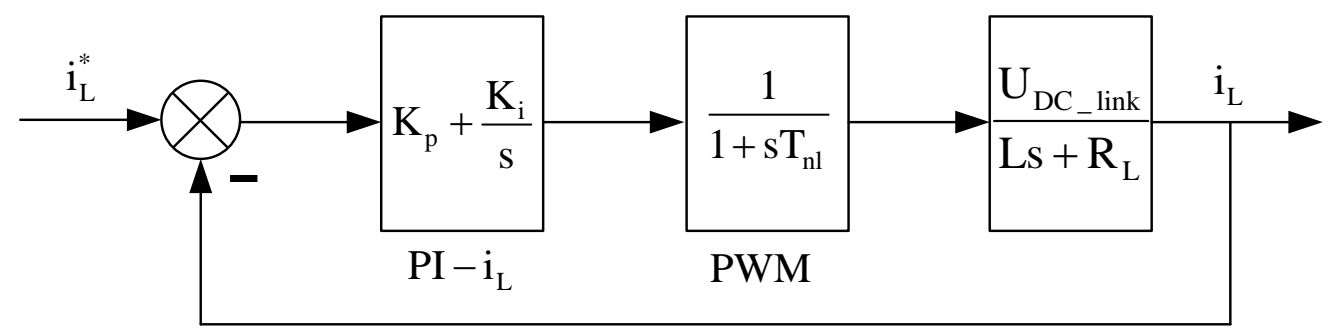

Figure 6. Current-loop control structure 


\subsection{Design control of the voltage-loop}

From the second equation of (11), building up the small-signal model:

$$
\frac{d \tilde{u}_{D C_{-} \text {link }}(t)}{d t}=\frac{1}{C} \cdot \tilde{l}_{\text {inv }}(t)-\frac{1}{C} \cdot \frac{U_{\text {sce }}}{U_{D C_{-} \text {linke }}} \cdot \tilde{\imath}_{L}(t)-\frac{1}{C} \cdot \tilde{d}(t) \cdot I_{L e}
$$

Applying the Laplace transform for (17) leads to (18).

$$
G_{v i}(s)=\left.\frac{\tilde{u}_{D C_{\text {link }}}(s)}{\tilde{l}_{L}(s)}\right|_{\substack{\tilde{d}=0 \\ \tilde{l}_{\text {inv }}=0}} \cong \frac{\tilde{u}_{D C_{\text {link }}}(s)}{\tilde{l}_{L}^{*}(s)} \mid=\frac{U_{s c e}}{C U_{D C_{\text {linke }} s} s}=\frac{K_{u}}{s}
$$

Assuming that synthesizing the current loop is extremely fast, accurate, so, ideally, its transfer function with a gain of unity as shown in Figure 7. Voltage controller -PI:

$$
G_{v c}(s)=k_{p u}\left(1+\frac{1}{T_{i u} s}\right)
$$

the closed- loop transfer function of voltage loop:

$$
G_{k u}(s)=\frac{G_{h u}(s)}{1+G_{h u}(s)}=\frac{k_{1} \frac{1+T_{i u} \cdot s}{s^{2}}}{1+k_{1} \frac{1+T_{i u} \cdot s}{s^{2}}}=\frac{k_{1}\left(1+T_{i u} \cdot s\right)}{s^{2}+k \cdot\left(1+T_{i u} \cdot s\right)}=\frac{k_{1} \cdot T_{i u} \cdot s+k_{1}}{s^{2}+k_{1} \cdot T_{i u} \cdot s+k_{1}}
$$

Finding values of $k_{p u}, k_{i u}$ by using symmetry optimal method,

$$
G_{k u}(s)=\frac{k_{1} \cdot T_{i u} \cdot s+k_{1}}{s^{2}+k_{1} \cdot T_{i u} \cdot s+k_{1}} \triangleq \frac{2 \cdot \xi \cdot \omega_{n} \cdot s+\omega_{n}^{2}}{s^{2}+2 \cdot \xi \cdot \omega_{n} \cdot s+\omega_{n}^{2}}
$$

where $\xi$ - Damping ratio $(\xi=0.71), \omega_{n}$ - oscillation cycle,

$$
\Rightarrow\left\{\begin{array} { c } 
{ k _ { 1 } = \omega _ { n } ^ { 2 } } \\
{ k _ { 1 } \cdot T _ { i u } = 2 . \xi . \omega _ { n } }
\end{array} \Leftrightarrow \left\{\begin{array} { c } 
{ k _ { 1 } = \frac { k _ { p u } \cdot k _ { u } } { T _ { i u } } = \omega _ { n } ^ { 2 } } \\
{ T _ { i u } = \frac { 2 \cdot \xi \cdot \omega _ { n } } { \omega _ { n } ^ { 2 } } = \frac { 2 . \xi } { \omega _ { n } } }
\end{array} \Leftrightarrow \left\{\begin{array}{c}
k_{p u}=-\frac{\omega_{n}^{2} \cdot T_{i u} \cdot C \cdot U_{D C_{-} \text {linke }}}{U_{\text {sce }}} \\
T_{i u}=\frac{2 \cdot \xi}{\omega_{n}}
\end{array}\right.\right.\right.
$$

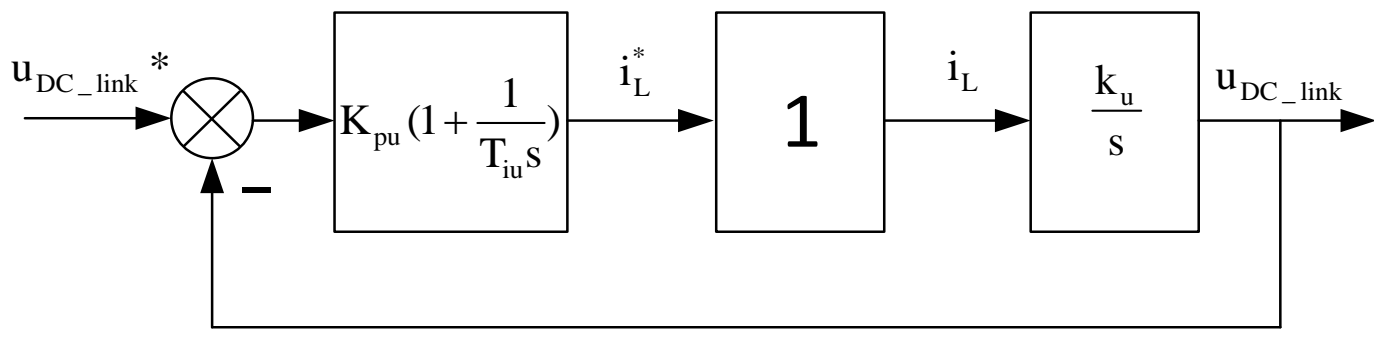

Figure 7. Voltage-loop control structure

\section{SIMULATION RESULTS}

The simulation data in Table 1 are collected from the high building 10 floor, Hanoi, Vietnam; parameters used in simulation are shown in Tables 2 and 3. Simulation scenarios elevator system run up with full load running down with full load when the elevator operates ten floors with total time about $50.76 \mathrm{~s}$. The speed of elevator running up full load is $1 \mathrm{~m} / \mathrm{s}$ in Figure $8(\mathrm{a})$, and down full load is $-1 \mathrm{~m} / \mathrm{s}$ in Figure $8(\mathrm{~b})$ accordance with the change of the power: 2600 and -1700 W shown in Figures 9(a) and 9(b). 
Table 1. Parameters of elevator system for the building ten floor high

\begin{tabular}{cc}
\hline Parameters & Values \\
\hline Number of floors & 10 \\
Number of floors & 10 \\
Distance between floors $(\mathrm{m})$ & 2.8 \\
Cabin's weight $(\mathrm{kg})$ & 1200 \\
Counterweight $(\mathrm{kg})$ & 1600 \\
Passengers weight $(\mathrm{kg})$ & 1000 \\
Maximum speed, $\mathrm{v}_{\max }(\mathrm{m} / \mathrm{s})$ & 1 \\
Acceleration and deceleration, $\mathrm{a}_{\max }(\mathrm{m} / \mathrm{s} 2)$ & 1.5 \\
Pulley diameter, $\mathrm{D}(\mathrm{m})$ & 0.4 \\
Transmission ratio, $\mathrm{i}$ & $1 / 20$ \\
Transmission performance, $\eta$ & $80 \%$ \\
Nominal power P $(\mathrm{kW})$ of each motor & 15 \\
Number of elevators & 01 \\
\hline
\end{tabular}

Table 2. Parameters of DC-DC converter

\begin{tabular}{cc}
\hline Parameters & Values \\
\hline Inductance, $\mathrm{L}(\mathrm{mH})$ & \\
Resistance, RL $(\Omega)$ & 0.05 \\
Capacitance of DC-Link capacitor $(\mu \mathrm{F})$ & 1000 \\
DC Link voltage $(\mathrm{V})$ & 650 \\
Parameters of super-capacitor $2 \mathrm{~F} / 325 \mathrm{~V}$ & \\
\hline
\end{tabular}

Table 3. Parameters of controllers

\begin{tabular}{ccc}
\hline Parameters & $K_{p}$ & $T_{i}$ \\
\hline Current loop & 0.0154 & 0.04 \\
Voltage loop & -0.284 & 0.0142 \\
\hline
\end{tabular}

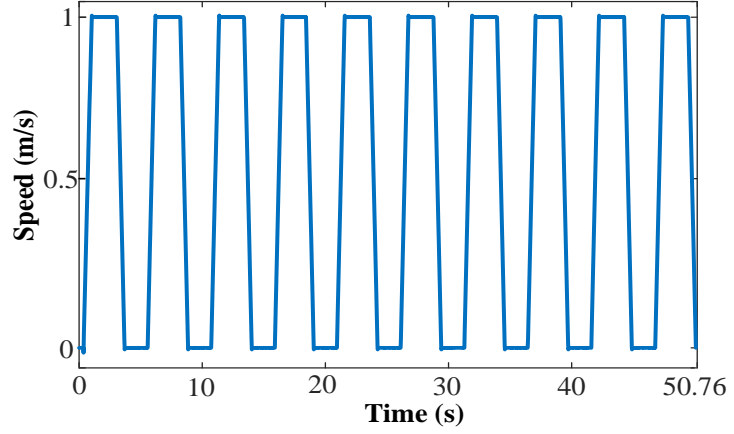

(a)

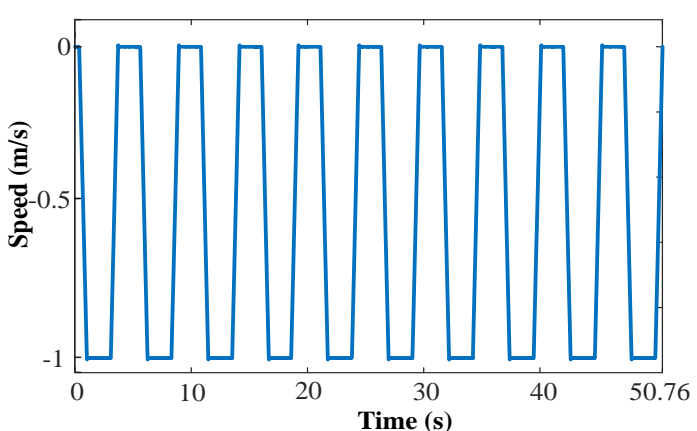

(b)

Figure 8. Speed responses (a) operating up with full load and (b) operating down with full load

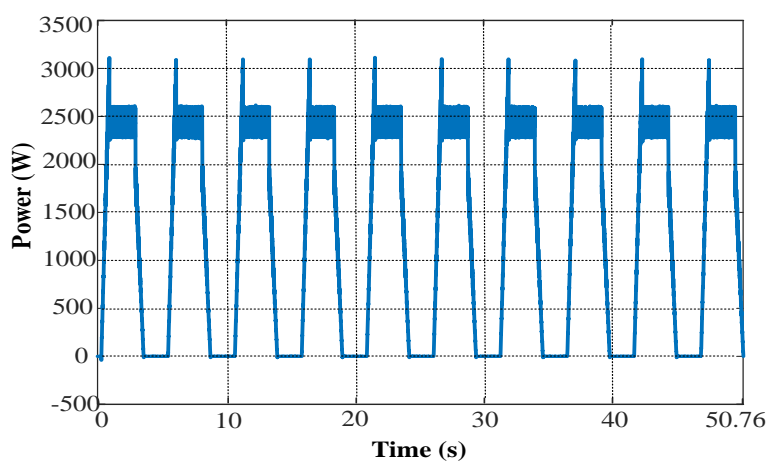

(a)

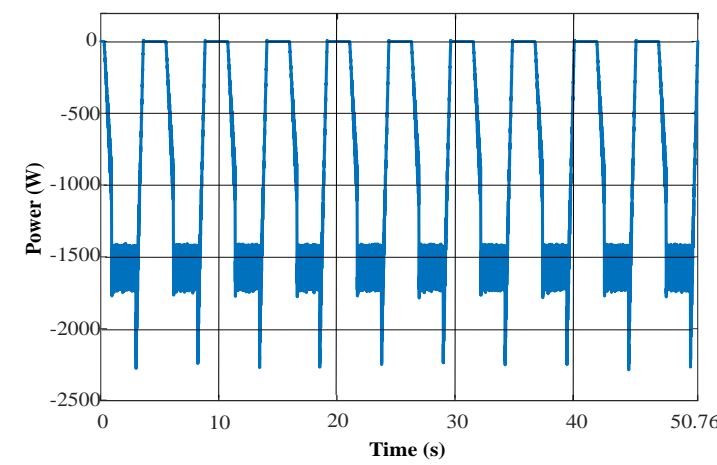

(b)

Figure 9. Power on shaft of traction motor when elevator is in full load up/down operation (a) operating up with full load and (b) operating down with full load 
Figures 10 and 11 compared $U_{d c-l i n k}$ with/without SCESS. Without SCESS, voltage fluctuation on bus DC when the elevator operates up with full load is from 620 to $650 \mathrm{~V} \mathrm{DC}$ as shown in Figure 10(a). The elevator operates down with full load $U_{d c \text {-link }}$ increases from 650 to $800 \mathrm{~V} \mathrm{DC}$ as shown in Figure 10(b). Meanwhile, using SCESS helping to reduce fluctuation of the grid voltage only around 650 VDC. Comparing level of consumption energy when the elevator in the ten-floor building moving up with full load the heaviest load without/with using SCESS in Figures 12 and 13 is $23 \mathrm{Wh}, 16 \mathrm{Wh}$ respectively; calculating percent of saving energy is $30 \%$. Additionally, unity consumption energy when the elevator runs down with full load without/with SCESS in Figures 14 and 15 is 1.23 and $0.6 \mathrm{~W}$ respectively.

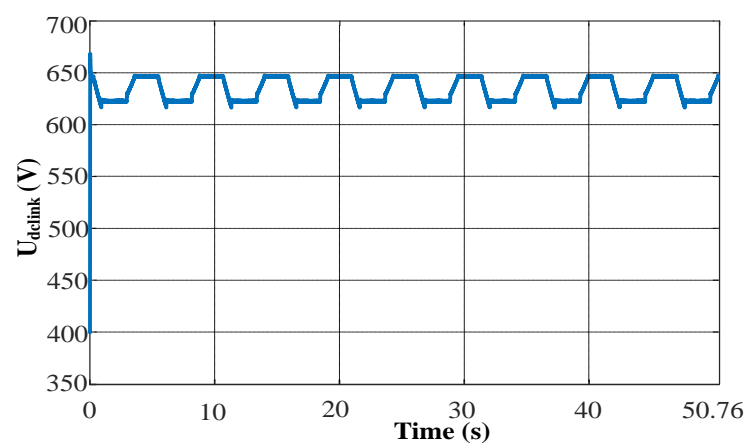

(a)

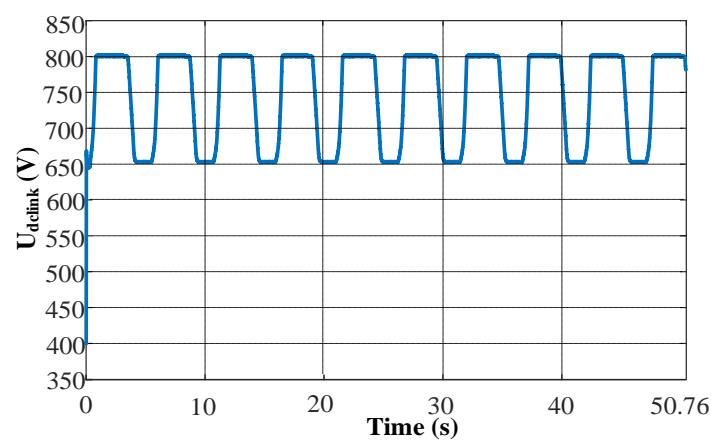

(b)

Figure 10. Responses of $U_{d c l i n k}$ with diode rectifier (a) operating up with full load and (b) operating down with full load

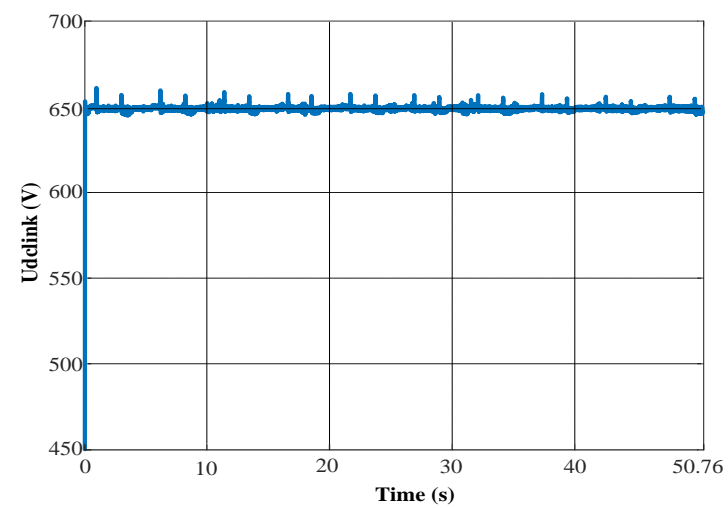

Figure 11. Response of $U_{d c l i n k}$ using SCESS

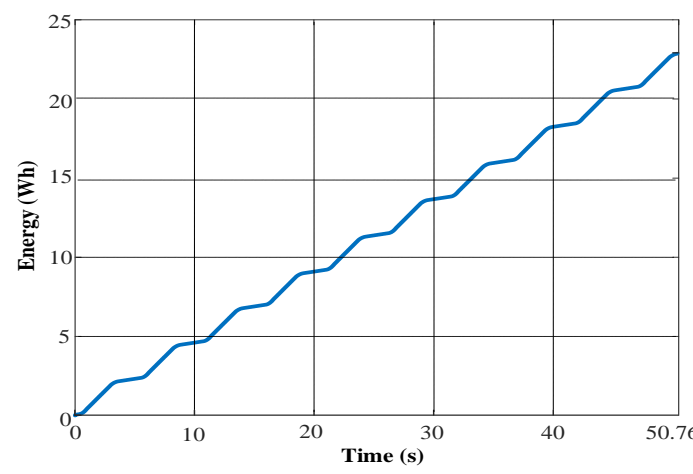

Figure 12. Response of unity consumption energy as operating up with full load

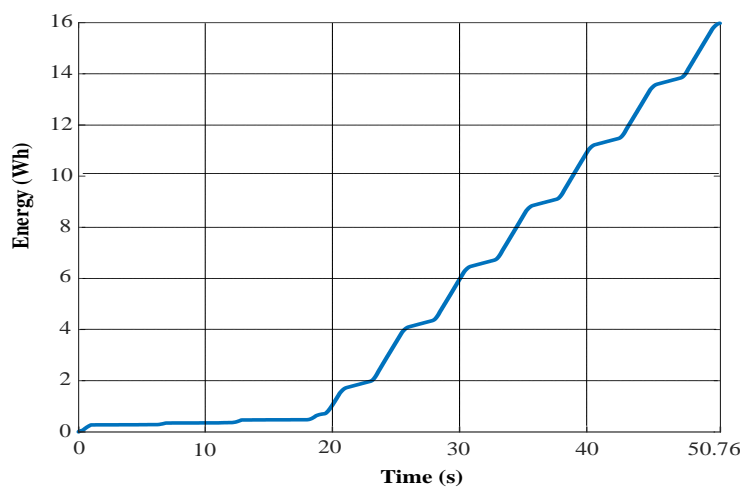

Figure 13. Response of unity consumption energy as operating up with full load using SCESS 


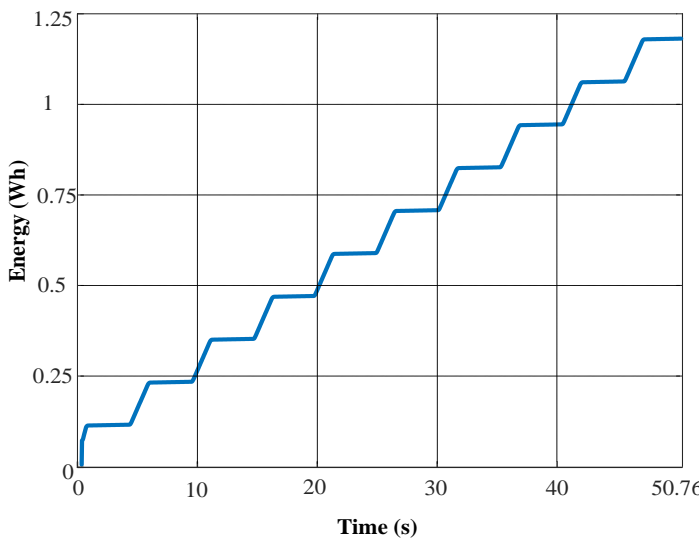

Figure 14. Response of unity consumption energy as operating down with full load

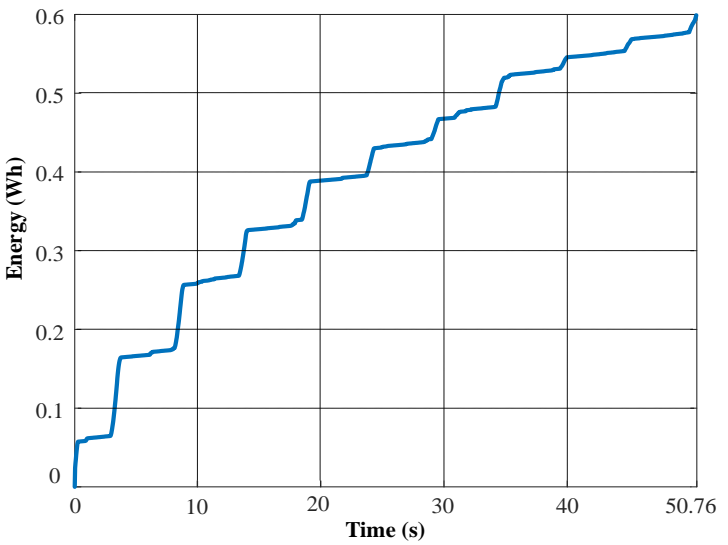

Figure 15. Response of unity consumption energy as operating down with full load using SCESS

\section{CONCLUSION}

In this paper, focusing on recuperating regenerative braking energy in elevator operation by using SCESS paralleled with bus DC. The simulation results of the elevator drive system in the ten-floor building integrated with SCESS showed energy can save up to $30 \%$.

\section{REFERENCES}

[1] G. Barney and L. Al-Sharif, Elevator traffic handbook: Theory and practice: Second edition. Routledge, 2015.

[2] Y. Zhang, Z. Yan, F. Yuan, J. Yao, and B. Ding, "A novel reconstruction approach to elevator energy conservation based on a DC micro-grid in high-rise buildings," Energies, vol. 12, no. 1, Art. no. 33, Dec. 2019, doi: 10.3390/en12010033.

[3] J. Zhang and Q. Zong, "Energy-saving scheduling optimization under up-peak traffic for group elevator system in building," Energy and Buildings, vol. 66, pp. 495-504, Nov. 2013, doi: 10.1016/j.enbuild.2013.07.069.

[4] M. H. Ali, "Design and implementation of an electrical lift controlled using PLC," International Journal of Electrical and Computer Engineering (IJECE), vol. 8, no. 4, pp. 1947-1953, Aug. 2018, doi: 10.11591/ijece.v8i4.pp1947-1953.

[5] M. F. Adak, N. Duru, and H. T. Duru, "Elevator simulator design and estimating energy consumption of an elevator system," Energy and Buildings, vol. 65, pp. 272-280, Oct. 2013, doi: 10.1016/j.enbuild.2013.06.003.

[6] A. D. Karlis, "Energy consumption estimation on lift systems: The advantages of VVVF drives," in Proceedings - 2014 International Conference on Electrical Machines, ICEM 2014, Sep. 2014, pp. 751-755, doi: 10.1109/ICELMACH.2014.6960265.

[7] C. Carrillo, E. Díaz-Dorado, J. Cidrás, and M. Silva-Ucha, "A methodology for energy analysis of escalators," Energy and Buildings, vol. 61, pp. 21-30, Jun. 2013, doi: 10.1016/j.enbuild.2013.01.038.

[8] L. Al-Sharif, "Modelling of escalator energy consumption,” Energy and Buildings, vol. 43, no. 6, pp. 1382-1391, Jun. 2011, doi: 10.1016/j.enbuild.2011.01.014.

[9] A. De Almeida, S. Hirzel, C. Patrão, J. Fong, and E. Dütschke, "Energy-efficient elevators and escalators in Europe: An analysis of energy efficiency potentials and policy measures," Energy and Buildings, vol. 47, pp. 151-158, Apr. 2012, doi: 10.1016/j.enbuild.2011.11.053.

[10] A. Mesemanolis, C. Mademlis, and I. Kioskeridis, "Neuro-fuzzy energy management system in elevator drive applications for maximum braking energy regenerative capability," in IET Conference Publications, 2014, vol. 2014, no. 628 CP, doi: $10.1049 / \mathrm{cp} .2014 .0494$

[11] N. Jabbour and C. Mademlis, "Improved control strategy of a supercapacitor-based energy recovery system for elevator applications," IEEE Transactions on Power Electronics, vol. 31, no. 12, pp. 8398-8408, 2016, doi: 10.1109/TPEL.2016.2516104.

[12] P. Kubade and S. K. Umathe, "Enhancing an elevator efficiency by using supercapacitor," in Proceedings of the 3rd IEEE International Conference on Advances in Electrical and Electronics, Information, Communication and Bio-Informatics, AEEICB 2017, Feb. 2017, pp. 502-505, doi: 10.1109/AEEICB.2017.7972364.

[13] A. Rufer and P. Barrade, "A supercapacitor-based energy-storage system for elevators with soft commutated interface," IEEE Transactions on Industry Applications, vol. 38, no. 5, pp. 1151-1159, Sep. 2002, doi: 10.1109/TIA.2002.803021.

[14] M. P. Shreelakshmi and V. Agarwal, "An energy efficient and environment friendly elevator system using ultracapacitor and fuel cell with power factor correction," in 2013 IEEE ECCE Asia Downunder - 5th IEEE Annual International Energy Conversion Congress and Exhibition, IEEE ECCE Asia 2013, Jun. 2013, pp. 721-727, doi: 10.1109/ECCE-Asia.2013.6579181.

[15] S. Lin, W. Song, Y. Chen, L. Luo, and Z. Feng, "Study on the model of elevator regeneration energy and its energy storage control method," in Proceedings - 2015 International Conference on Smart Grid and Clean Energy Technologies, ICSGCE 2015, Oct. 2016, pp. 125-128, doi: 10.1109/ICSGCE.2015.7454282.

[16] K. Kafalis and A. D. Karlis, "Comparison of flywheels and supercapacitors for energy saving in elevators," in 2016 IEEE Industry Applications Society Annual Meeting, Oct. 2016, pp. 1-8, doi: 10.1109/IAS.2016.7731825.

[17] E. Bilbao, P. Barrade, I. Etxeberria-Otadui, A. Rufer, S. Luri, and I. Gil, "Optimal energy management strategy of an improved elevator with energy storage capacity based on dynamic programming," IEEE Transactions on Industry Applications, vol. 50, no. 2, pp. 1233-1244, Mar. 2014, doi: 10.1109/TIA.2013.2276015.

[18] D. A. A. Osman, R. Baharom, D. Johari, M. N. Hidayat, and K. S. Muhammad, "Development of active power filter using rectifier boost technique," International Journal of Power Electronics and Drive Systems (IJPEDS), vol. 10, no. 3, pp. 1446-1453, Sep. 2019, doi: 10.11591/ijpeds.v10.i3.pp1446-1453. 
[19] M. Dabbaghjamanesh, A. Moeini, M. Ashkaboosi, P. Khazaei, and K. Mirzapalangi, "High performance control of grid connected cascaded HBridge active rectifier based on type II-fuzzy logic controller with low frequency modulation technique," International Journal of Electrical and Computer Engineering (IJECE), vol. 6, no. 2, pp. 484-494, Apr. 2016, doi: 10.11591/ijece.v6i2.9442.

[20] I. Yuniantoro, R. Setiabudy, and R. Gunawan, "Comparison of voltage vector control based on duty cycle analysis in three phase four leg system of active filter," International Journal of Electrical and Computer Engineering (IJECE), vol. 6, no. 4, pp. 1395-1405, Aug. 2016, doi: 10.11591/ijece.v6i4.8793.

[21] N. P. Quang and J.-A. Dittrich, Vector Control of Three-Phase AC Machines. Berlin, Heidelberg: Springer Berlin Heidelberg, 2008.

[22] R. Mat Ariff, D. Hanafi, W. M. Utomo, N. Muhammad Zin, S. Y. Sim, and A. Aida Bohari, "Takagi-sugeno fuzzy perpose as speed controller in indirect field oriented control of induction motor drive," International Journal of Power Electronics and Drive Systems (IJPEDS), vol. 8, no. 2, pp. 513-521, Jun. 2017, doi: 10.11591/ijpeds.v8.i2.pp513-521.

[23] A. Pradhan and B. Panda, "A simplified design and modeling of boost converter for photovoltaic sytem," International Journal of Electrical and Computer Engineering (IJECE), vol. 8, no. 1, pp. 141-149, Feb. 2018, doi: 10.11591/ijece.v8i1.pp141-149.

[24] E. Setiawan, T. Hirata, and I. Hodaka, "Accurate symbolic steady state modeling of buck converter," International Journal of Electrical and Computer Engineering (IJECE), vol. 7, no. 5, pp. 2374-2381, Oct. 2017, doi: 10.11591/ijece.v7i5.pp2374-2381

[25] R. Palanisamy, K. Vijayakumar, V. Venkatachalam, R. M. Narayanan, D. Saravanakumar, and K. Saravanan, "Simulation of various DC-DC converters for photovoltaic system," International Journal of Electrical and Computer Engineering (IJECE), vol. 9, no. 2, pp. 917-925, Apr. 2019, doi: 10.11591/ijece.v9i2.pp917-925.

[26] S. Bacha, I. Munteanu, and A. I. Bratcu, Power Electronic Converters Modelling and Control, no. 9781447154778.2008.

[27] C. H. Houpis and S. N. Sheldon, Linear control system analysis and design with MATLAB. CRC Press, 2013.

\section{BIOGRAPHIES OF AUTHORS}

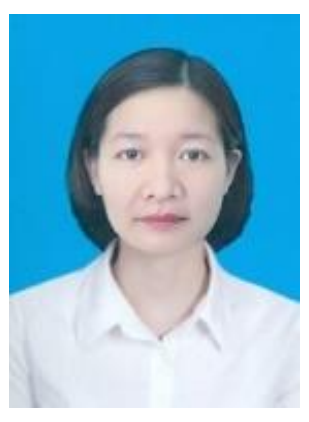

(क)
An Thi Hoai Thu Anh (iD SC P received her Engineer (1997), M.Sc. (2002) degrees in Industrial automation engineering from Hanoi University of science and technology, and completed $\mathrm{PhD}$ degree in 2020 from University of transport and communications (UTC). Now, she is a lecturer of Faculty of Electrical and Electronic Engineering under University of Transport and Communications (UTC), Vietnam. Her current interests include power electronic converters, electric motor drive, saving energy solutions applied for industry and transportation. She can be contacted at email: htanh.ktd@utc.edu.vn.

Luong Huynh Duc (D) S SC P is the 4th year undergraduate student at Faculty of Electrical and Electronic Engineering under University of Transport and Communications (UTC), Vietnam. His current interests include power electronic converters, electric motor drive. $\mathrm{He}$ can be contacted at email: huynhduc0312hn@gmail.com. 